\title{
Pengembangan Sistem Informasi Akademik Sekolah Menengah Kejuruan Se-Kab. Sorong Papua Barat
}

\author{
Novita Wulandari \& Jusrianto AS \\ UNIMUDA Sorong \\ Email: novitawulandariumar@gmail.com \\ Jusrianto33@gmail.com
}

\begin{abstract}
Based on PP 17, 2007 article 49; "Management of educational units at elementary and secondary levels implements school-based management as demonstrated by independence, partnership, participation, openness, and accountability". School efforts to achieve open and measurable schools (management accountability) one of them is with the updating of technology in the field of school management in this case the application of Academic Information System so that expected flow of information can be distributed quickly and accurately and synergistically in decision making. But in fact the application of Academic Information System (SIA) in schools tend to be just a trend only, the system used is not in accordance with the needs or appropriate but difficult to use. As a result SIA at school becomes useless. The purpose of this study is to obtain an accurate need analysis of academic vocational school academic information system so that it can produce a uniform standard SIA school criteria. The research method used is quantitative by collecting data in the field directly through observation, interview and questionnaire. The results of data processing is used as a tool to describe the results of research and become the reference of the publication of the standard development of academic information system of SMK throughout Kab.Sorong.
\end{abstract}

Keywords: Analysis, SMK Academic Information System, SIA standard.

Abstrak: Berdasarkan PP 17, 2007 pasal 49; "Manajemen unit pendidikan di tingkat dasar dan menengah menerapkan manajemen berbasis sekolah seperti yang ditunjukkan oleh kebebasan, kemitraan, partisipasi, keterbukaan, dan akuntabilitas". Upaya sekolah untuk mencapai sekolah terbuka dan terukur (manajemen akuntabilitas) salah satunya adalah dengan pemutakhiran teknologi di bidang manajemen sekolah dalam hal ini penerapan Sistem Informasi Akademik sehingga diharapkan aliran informasi dapat didistribusikan secara cepat dan akurat dan sinergis dalam pengambilan keputusan. Tetapi sebenarnya penerapan Sistem Informasi Akademik (SIA) di sekolah cenderung hanya sekedar tren saja, sistem yang digunakan tidak sesuai dengan kebutuhan atau tepat tetapi sulit digunakan. Akibatnya SIA di sekolah menjadi tidak berguna. Tujuan penelitian ini adalah untuk memperoleh analisis kebutuhan sistem informasi akademik akademik SMK yang akurat sehingga dapat menghasilkan standar sekolah SIA berstandar seragam. Metode penelitian yang digunakan adalah kuantitatif dengan mengumpulkan data di lapangan secara langsung melalui observasi, wawancara dan kuesioner. Hasil pengolahan data digunakan sebagai alat untuk menggambarkan hasil penelitian dan menjadi acuan publikasi pengembangan standar sistem informasi akademik SMK se-Kab.Sorong.

Kata kunci: analisis, SMK, Sistem informasi akademik, standar SIA

\section{Pendahuluan}

Kecenderungan masyarakat menggunakan dan memanfaatkan teknologi informasi membuat beberapa pakar di kalangan pendidikan dan sekolah menggiring gagasan untuk membuat terobosan teknologi informasi bagi pendidikan salah satunya adalah dalam hal manajerial sekolah dengan sistem Manajemen Berbasis Sekolah (MBS). Keandalan teknologi informasi dalam mengelola data rutin 
menjadi sebuah informasi akurat dianggap menjadi tawaran solusi yang baik dan sangat dibutuhkan. Perubahan dari sistem manual ke sistem informasi terkomputerisasi tidak hanya menyangkut perubahan teknologi tetapi juga perubahan perilaku dan organisasi (Bodnar dan Hopwood, 2001) mengakibatkan hal ini sangat dibutuhkan. Sekolah sebagai salah satu bentuk organisasi pendidikan tengah secara masif berbenah untuk dapat mengimplementasikan teknologi informasi di dalam sistem pendidikan dan atau sistem manajerial sekolah mereka.

Teknologi informasi yang terintegrasi dengan sistem sekolah atau biasa dikenal dengan istilah SIA, banyak yang belum berdampak positif bagi sekolah yang menerapkannya. SIA itu sendiri kini cenderung menjadi beban bagi sekolah baik secara finansial dan teknis. Untuk mengoperasikan SIA sebuah sekolah minimal harus memiliki seorang tenaga admintetap yang bertugas memantau SIA, namun kemanfaatan SIA itu sendiri belum bisa dirasakan langsung oleh warga sekolah karena biasanya sebuah SIA diterapkan di sekolah hanya berdasarkan tren dari sekolah lain, atau gaung dari kebijakan pemerintah yang terkesan tergesa-gesa.

Faktor lain yang membuat tidak efektifnya sebuah sistem informasi akademik di sekolah adalah sistem yang tidak user friendly. Artinya bahwa sistem yang diterapkan mungkin saja telah sesuai dengan kebutuhan sekolah tapi tidak mudah untuk digunakan terutama bagi pengguna yang tergolong kategori awam. Hal tersebut semakin menjadikan alasan bagaimana sebuah sistem akhirnya ditinggalkan oleh penggunanya dan menjadi tidak bermanfaat.

Pembangunan sebuah sistem hendaklah berdasarkan analisis kebutuhan yang sangat mendasar dan prioritas. Kebutuhan prioritas disebuah organisasi sekolah akan sangat beragam dan sangat mudah berubah, oleh sebab itu kebutuhan yang spesifik menjadi kunci utama dibangunnya sebuah sistem informasi akademik. Meskipun beragam dan sangat bergantung pada faktor-faktor eksternal sekolah (seperti kondisi geografis dan kondisi masyarakat di lingkungan sekolah) sebuah sistem informasi akademik harus juga mampu mengakomodir ketersediaan informasi sekolah yang standar dan dapat digeneralisasi. Sehingga berdasarkan informasi yang terdapat di SIA sekolah, secara awam masyarakat atau pihak berwenang mampu mengambil simpulan teoritis bagaimana kondisi sekolah tersebut berdasarkan data empirik dari SIA sekolah.

Melihat fenomena tersebut di atas, perlu kiranya berhenti sejenak untuk memikirkan ulang pemanfaatan sebuah SIA dapat dibangun dan diimplementasikan di sekolah dengan user friendly, tepat guna dan bermanfaat, sehingga kelak tidak perlu lagi terjadi pemborosan anggaran sekolah yang terbuang percuma karena menerapkan sebuah SIA yang tidak memberikan efek samping signifikan atau bahkan tidak bermanfaat sama sekali karena tidak sesuai dengan kebutuhan sekolah atau karena sulit digunakan. Oleh sebab itu, penulis menganggap penting mengangkat isu mengenai analisis kebutuhan sistem informasi akademik sekolah sehingga nanti akan melahirkan sebuah standar sistem informasi 
yang dapat diterapkan sesuai dengan kebutuhan sekolah secara spesifik namun mampu memberi informasi yang dapat diterima secara umum.

\section{Metode Penelitian}

\subsection{Jenis Penelitian}

Penelitian inimenggunakan pendekatan kuantitatif, karena menampilkan hasil statistik yang disajikan dengan angka. Tujuan pendekatan kuantitatif yaitu mengembangkan hubungan antaravariabelterukur,danprosespenelitiannya berurut dikembangkan sebelum studi dimulai (Schumacher \&Millan, 2001). Metode pendekatan yang digunakan adalah metode survey, penelitian survei adalah penelitian yang dilakukan pada populasi besar atau kecil, tetapi data yang dipelajari adalah dari sampel yang diambil dari populasi tersebut, untuk menemukankejadian-kejadianrelatif,distribusi, dan hubungan-hubunganantar variabel sosiologis maupun psikologis (Keringler, 1973 dalam Sugiyono2013).

\subsection{Kerangka Penelitian}

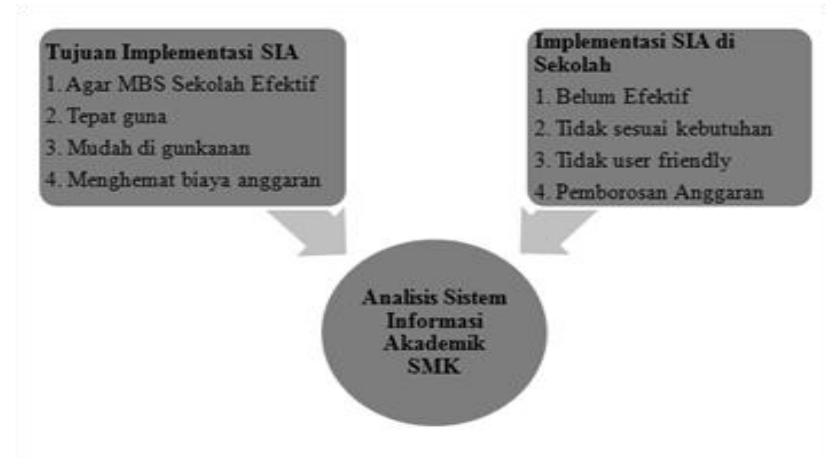

\subsection{Tempat Penelitian dan Jadwal Penelitian}

Penelitian akan dilakukan di secara sampling jenuh, dimana penentuan sampel dilakukan jika semua anggota populasi digunakan sebagai sampel (Sugiyono, 2007). Proses pengambilan sampel dengan melakukan observasi ke seluruh SMKdi Kab. Sorong. Proses penelitian yang akan dilaksanakan diharapkan selesai dalam 1 tahun.

\subsection{Populasi dan Teknik Pengambilan Sampel}

Populasi pada penelitian ini adalah Sekolah Menengah Kejuruan Negeri se-Kab. Sorong Papua Barat. Adapun Teknik sampling yang digunakan pada penelitian ini adalah sampling jenuh yaitu sampling diambil secara keseluruhan karena jumlah populasinya kurang dari 30.

\subsection{Teknik Pengumpulan Data}




\subsubsection{Observasi}

Dalam melakukan observasi peneliti menggunakan observasi terbuka, dimana peneliti dalam melakukan pengumpulan data menyatakan sebenarnya kepadasumber data bahwa sedang melakukan penelitian.

\subsubsection{Wawancara}

Wawancara mer upakan metode pengumpulan data dengan jalan tanya jawab sepihak yang dilakukan secara sistematis dan berlandaskan kepada tujuan penelitian (Lerbin, 1992 dalam Hadi, 2007).

\subsubsection{Kuesioner}

Kuisioner dilakukan dengan menjawab secara jujur tentang kondisi sebenarnya mengenai implementasi sistem informasi akademik sekolah dan manfaatnya.

\section{Hasil dan Pembahasan}

Perancangan dilakukan dengan mengidentifikasi langkah-langkah sistematis dalam penerapana sistem informasi akademik yang diimplementasikan penggunaannya disekolah yang dimulai dari pengembangan sistem informasi akademik dan kajian atau uji produk akhir sistem informasi yang telah dirancang pada Sekolah Menengah Kejuruan (SMK) yang memenuhi syarat validitas, dan keefektifan.

\subsection{Perancangan Sistem Informasi Akademik Sekolah}

\subsubsection{Studi Pendahuluan/AnalisisKebutuhan}

Tahap analisis kebutuhan dilakukan untuk mendapatkan berbagai informasi tentang SMK yang membutuhkan sistem informasi akademik dan telah didukung oleh infrastruktur dan jaringan internet pada lingkup daerah penelitian. Pengawasan peserta didik merupakan hal yang sangat penting dalam proses pendidikan guna mencapai hasil maksimal dari pendidikan yang ingin dicapai. SMK Negeri 1 Minasate'ne sebagai salah satu sekolah yang membuka jurusan teknik komputer jaringan merupakan salah satu sekolah yang memenuhi syarat untuk menunjang keberhasilan dan kehandalan sistem informasi yang akan diterapkan.

\subsubsection{Analisis Sistem yang berjalan}

Analisis sistem yang sedang berjalan dilakukan dengan tujuan untuk mengetahui proses kerja yang sedang berjalan. Pokok-pokok yang di analisis meliputi analisis prosedur atau aliran data, diagram konteks,dan data flow diagram. Ini dilakukan untuk mengevaluasi dan memberikan gambaran rencana pemecahan masalah yang dihadapi.

Perancangan sistem informasi akademik ini perlu dikembangkan karena sistem yang sedang berjalan saat ini belum terdapat sistem komputerisasi dan informasi yang belum akurat sehingga 
mengalami keterlambatan serta memerlukan waktu yang lama dalam pencarian data.

\subsubsection{Analisis Modul}

Analisis modul menggambarkan bagaimana dan untuk apa saja dokumen- dokumen digunakan dalam sistem informasi akademik. Untuk itu analisa modul merupakan salah satu yang dapat membantu dalam perancangan atau dari sistem selanjutnya, dalam sistem informasi akademik ini terdapat 5 modul yaitu (1) Modul akademik, (2) Modul Kepegawaian, (3) Modul Info Guru, (4) Modul Info Siswa, (5) Modul Sms gateway.

\subsubsection{Analisis Prosedur Yang Sedang Berjalan Berikut adalah analisis prosedur yang sedang berjalan:}

1) Data siswa dan guru diberikan kepada bagian akademik, oleh bagian akademik data tersebut di catat dan dibuat arsip dan dari arsip itu dibuat laporan data siswa dan guru untuk civitas akademik sekolah.

2) Dari arsip data siswa dibuat data kelas, dari data kelas kemudian dibuat data penilaian dan absensi siswa yang nantinya dibuat data laporan untuk guru dan orang tua.

3) Data guru diberikan kepada bagian akademik, oleh bagian akademik data guru tersebut dicatat dan dibuat arsip, dari arsip data guru tersebut dibuat untuk pembagian tugas mengajar untuk pembuatan jadwal pelajaran, penilaian, dan kalender akademik.

\subsubsection{Analisis Desain dan Penggunaan Modul Sistem Informasi Akademik Sekolah}

\subsubsection{Perancangan database}

Sistem informasi akademik ini terdiri dari 5 modul yaitu: (1) Akademik, (2) Kepegawaian, (3) Info guru, (4) Info Siswa, (5) Smsgateway. Masing-masing modul hanya dapat diakses oleh pengguna yang berkepentingan sesuai dengan penambahan pengguna oleh administrator. Desain sistem dimulai dengan perancangan data base yang merupakan salah satu komponen penting dalam perancangan suatu sistem informasi. Penggunaan data base ditunjukan agar dalam pengoperasiannya dan pengimplementasiannya dapat diperoleh informasi yang lebih lengkap serta mempermudah proses manipulasi data.

Perancangan database dimulai dari perancangan struktur file. Tujuan dari perancangan struktur file ini yaitu untuk menentukan nama field, tipe field dari file tersebut yang ada pada file.

\subsubsection{Perancangan antarmuka}

Program dapat didefinisikan sebagai kumpulan dari instruksi-instruksi atau perintahperintah terperinci yang sudah disiapkan oleh komputer sehingga dapat melakukan fungsi-fungsi sesuai dengan yangtelah ditentukan. Tujuan dari pembuatan program ini adalah untuk mempermudah dan mempercepat aktivitas yang berhubungan dengan pengolahan data dan untuk 
membentuk suatu sistem yang lebih baik. Sistem ini juga diharapkan dapat menjadi kontrol bagi orang kepada anaknya sebagai bahan rujukan dalam mendidik anak mereka.

\subsection{Data Uji Coba Produk}

\subsubsection{Validasi Ahli}

Uji coba model atau produk bertujuan untuk mengetahui apakah produk yang dibuat layak atau tidak untuk digunakan. Uji coba model atau produk juga melihat sejauh mana produk yang dibuat dapat mencapai sasaran dan tujuan. Dalam hal ini, untuk validasi produk digunakan 2 validator dimana masing-masing validator mempunyai peran dalam mengevaluasi produk yang dibuat. Validator 1 mempunyai bidang keahlian di Teknologi Pendidikan dan Kejuruan sedangkan validator mempunyai keahlian dibidang website dan multimedia. Validator dengan bidang keahlian mengenai teknologi kejuruan memvalidasi aspek yang berhubungan dengan aspek penggunaan produk dimana terdapat 5 indikator yang mencakup keseluruhan aspek penelitian. Validator 2 dengan bidang keahlian website dan multimedia mamvalidasi pada aspek konten dan isi dimana terdapat 11 indikator yang berhubungan dengan rancangan dan desain website. Tahapan validasi dilakukan dengan memperlihatkan secara langsung kepada validator hasil produk yang telah dibuat, meskipun berbasis web tapi dalam pelaksanaan validasi hanya dilakukan pengujian internal yang biasa disebut dengan localhost dimana komputer sebagai server utama. Setelah melihat dan menguji produk yang ada kemudian masing-masing validator member komentar dan saran serta menilai produk yang telah dihasilkan.

\subsubsection{Uji Coba Kelompok Kecil}

Uji coba kelompok kecil melibatkan 10 orang siswa dan 1 guru dari dari mata pelajaran yang berbeda pula serta 1 pegawai. Hal ini dilakukan untuk melihat sejauh mana sistem bekerja. Uji coba dilakukan terhadap produk sesuai dengan prosedur pengembangan yang telah disebutkan pada metode penelitian. Untuk uji coba ini dilakukan validasi terlebih dahulu terhadap produk yang akan diuji cobakan. Responden yang menjadi subjek pada uji coba ini yaitu pegawai, guru dan siswa SMK Negei 1 Minasate'ne. Untuk validasis sistem informasi ini menilai dari 5 indikator yaitu: Kualitas sistem, Kualitas Sistem Informasi, Penggunaan Sistem Informasi, Kepuasn pemakai, dan Dampak bagi sekolah.

Tahapan uji coba yang dilakukan diambil dari instrumen validasi untuk aspek pengguna dimana pada instrument tersebut mencakup mengenai proses input dan output yang ada pada sistem informasi. Hal ini dilakukan kepada semua civitas akademik yang telah disebutkan diatas karena kesemuanyamerupakan pengguna dalam sistem informasi akademik sekolah ini. Aspek penilaian yang dilakukan oleh validator pada tahap ini adalah menilai setiap aspek yang disajikan yakni, kualitas sistem, kualitas informasi sistem yang dihasilkan, penggunaan sistem informasi, kepuasan pemakai dan dampak 
bagi sekolah.

\subsubsection{Uji Coba Lapangan/Diperluas}

Uji coba lapangan merupkana uji coba utama untuk mengukur apakah sistem informasi akademik sekolah layak dipergunakan dan diterapkan. Instrument yang digunakan dalam uji coba lapangan tidak berbeda jauh dengan uji coba yang telah dilakukan sebelumnya, yang berbeda hanya penambahan jumlah responden ujicoba. Uji coba lapangan melibatkan 20 orang siswa dan 2 orang guru serta 1 pegawai pada SMK Negeri 1 Minasate'ne.

Uji coba ini merupakan uji coba sebenarnya dan diharapkan hasil dari uji coba ini menghasilkan sebuah protyppe sistem informasi akademik yang siap digunakan oleh sekolah. Meskipun dalam uji coba lapangan ini masih ada uji coba yang dilakukan dengan simulasi dikarenakan data yang sebenarnya belum ada sehingga memakai data manipulasi untuk melihat sejauh mana sistem bekerja secara keseluruhan. Namun diharapkan manipulasi data yang ada tidak mengurangi esensi dari sistem yang akan diujicoba.

\subsection{Analisis Data Keefektifan}

Nilai keefektifan suatu sistem informasi diperoleh berdasarkan kriteria yang telah disebutkan sebelumnya pada bab II. Suatu sistem informasi dikatakan efektif apabila memenuhi ciri-ciri sebagai berikut: (1)Reliable yang meliputi bebas dari kesalahan dan akurat, (2) Relevant yang meliputi berguna dan bernilai, (3) Timely yang meliputi cepat, (4)Complete yang meliputi lengkap, dan (5) Understandable yang meliputi mudah dimengerti. Ciri-ciri sistem informasi yang baik yang meliputi 5 poin diimplementasikan menjadi sebuah indikator pada aspek penilaian pengguna dimana terdapat 5 indikator.

\subsection{Kajian Produk Akhir Sistem Informasi Akademik}

Pada proses pengembangan sistem informasi menggunakan prototyping model yang terdiri dari 7 tahap yaitu : (1) Mengumpulkan dan menganalisis kebutuhan, (2) Melakukan perancangan cepat, (3) Membangun sebuah prototype, (4) Evaluasi dilakukan oleh konsumen atas prototype, (5) Perubahan rancangan dan prototype, (6) Apabila ada kekurangan dengan prototype yang telah dibangun maka akan diulangi langkah 5, dan (7) Apabila prototype sudah sesuai dengan yang diinginkan, pengembang produk berskala besar dapat dimulai.

\section{Simpulan}

\subsection{Kesimpulan}

Berdasarkan hasil pembahasan dan analisis, maka dapat diambil beberapa kesimpulan sebagai berikut :

1) Perancangan sistem informasi akademik di SMK Negeri 1 Minasate'ne dilakukan melalui langkah- 
langkah:

a. Studi pendahuluan/ analisis kebutuhan yang dilakukan untuk mendapatkan berbagai informasi tentang SMK yang membutuhkan sistem informasi akademik dan telah didukung oleh infrastruktur dan jaringan internet pada lingkup daerah penelitian.

b. Analisis sistem yang sedang berjalan dilakukan dengan tujuan untuk mengetahui proses kerja yang sedang berjalan. Pokok- pokok yang di analisis meliputi analisis prosedur atau aliran data, diagram konteks, dan data flow diagram. Ini dilakukan untuk mengevaluasi dan memberikan gambaran rencan apemecahan masalah yang dihadapi.

c. Analisis desain dan penggunaan modul sistem yang meliputi perancangan database dan perancangan antar muka.

Perancangan program menghasilkan prototype awal yang divalidasi kepada ahli media dan meteri. Selanjutnya diuji cobakan kepada responden dengan 2 tahap yaitu uji coba kelompok kecil dan uji coba diperluas/lapangan. Sistem informasi akademik yang dihasilkan telah efektif dan layak digunakan dalam manajemen sekolah.Hal ini dibuktikan dengan terpenuhinya ciri- ciri informasi yang efektfif yang dituangkan dalam indikator dengan kategori minimal baik dari hasil pengujian. Ciri-ciri sistem informasi akademik yang dimaksud yaitu : (1) Reliable yang meliputi bebas dari kesalahan dan akurat,(2)Relevant yang meliputi berguna dan bernilai, (3) Timely yang meliputi cepat, (4) Complete yang meliputi lengkap, dan (5) Understandable yang meliputi mudah dimengerti.

\section{Daftar Pustaka}

Ackoff, R.I (1989). From Data to Wisdom. Journal of Alilied System Analysis. Vol-16. P-39. Aras (2003). Pengaruh Pengabdosian Teknologi Baru terhadap Peningkatan Efektifitas dan Kinerja Pengembangan bersama Sistem Informasi Manajemen. Jakarta. Thesis S2 Universitas Bina Nusantara Internasional Jakarta.

Arikunto, Suharsimi (1993). Prosedur Penelitian: Suatu Pendekatan Praktek. Jakarta. Rineka Cipta Arikunto, Suharsimi (2005). Manajemen Penelitian. Jakarta. Rineka Cipta

Hadi, Sutrisno (2007). Metodologi Research. Jogjakarta. Andi.

Hanif Al Fatha (2007). Analisi dan Perancangan Sistem Informasi. Jogjakarta. Andi. Jogiyanto, HM (2005). Analisis dan Desain Sistem Informasi: Pendekatan Terstruktur Teori dan Praktik Aplikasi Bisnis. Jogjakarta. Andi.

McMillan, J. H. \& Schumacher, S (2001). Research in Education (Fifth ed). Newyork. Longman

Mukhtar (1999). Audit Sistem Informasi, Jakarta. Rieneka Cipta

Northcraft, Neale (1994). Organizational Behavior:A Management Challenge. Forth Worth Tx: Dryden.Raco. J. R. (2010). Metode Penelitian Kuantitatif, Jakarta: PT. Grasindo

Rapport.L.Justin. (2010). Facebook Marketing: Designing Your Next Marketing Campaign, Ist. United State of America. Pearson Education,Inc.

Rochaety, Eti. Rahayuningsih. (2009). Sistem Informasi Manajemen Pendidikan, Jakarta, PT. BumiAkasara

Sudjana. (1986). Metode Statistika. Bandung. 
Jurnal Pendidikan; Vol. 6, No. 2; Juli 2018. ISSN: 2337-7607; EISSN : 2337-7593

Tarsito Sugiyono (2002). Metode Penelitian Administrasi. Bandung. CV. Alfabeta. Sugiono (2007). Statistika untuk Penelitian, Bandung, Alfabet 